Sitti Musdalifah, Syamsidar Hs, Dan Suriani

Dekolagenasi Limbah Tulang paha Ayam Broiler (Gallus domesticus) oleh $\mathcal{N a t r i u m ~ H i d r o k s i d a ~}$

(NaOH) untuk Penentuan Kadar Kalsium (Ca) Dan Fosfat (PO $\left.{ }_{4}\right)$

\title{
DEKOLAGENASI LIMBAH TULANG PAHA AYAM BROILER \\ (Gallus domesticus) OLEH NATRIUM HIDROKSIDA (NaOH) UNTUK PENENTUAN KADAR KALSIUM (Ca) DAN FOSFAT $\left(\mathrm{PO}_{4}\right)$
}

\author{
Sitti Musdalifah, Syamsidar HS, dan Suriani \\ Jurusan Kimia, Fakultas Sains dan Teknologi, UIN Alauddin Makassar \\ Email:Ifah1503@ rocketmail.com
}

\begin{abstract}
This research aims to determine the level of Calcium (Ca) and Phosphate $\left(\mathrm{PO}_{4}\right)$, and the influence of broilers femur submersion in $\mathrm{NaOH}$ toward Calcium $(\mathrm{Ca})$ and Phosphate $\left(\mathrm{PO}_{4}\right)$ levels. The method used in this research is decollagenation of broilers (Gallus domesticus) femur. Then, the parameters observed are chemical tests of Calcium $(\mathrm{Ca})$ and Phosphate $\left(\mathrm{PO}_{4}\right)$ levels. Decollagenation treatment was carried out in three soaking-time variation such as 42 hours, 72 hours, and 96 hours to respectively determine the Calcium and Phosphate levels. The result shows that soaking-time of femur does not give significant effect to increased levels of Calcium (Ca) and Phosphate $\left(\mathrm{PO}_{4}\right)$.
\end{abstract}

Keywords:broiler femur waste, Calcium,decollagenation, $\mathrm{NaOH}$, Phosphate.

\section{PENDAHULUAN}

Indonesia merupakan salah satu negara dengan jumlah penduduk terbanyak. Banyaknya jumlah penduduk ini sangat mempengaruhi peningkatan kebutuhan akan makanan. Kebutuhan makanan sangat penting untuk kelangsungan hidup manusia, terutama makanan yang kaya akan gizi. Salah satu makanan yang mengandung gizi yang cukup yaitu daging, baik itu daging sapi, kambing ayam dan lain-lain. Namun saat ini, daging yang banyak dikonsumsi oleh masyarakat yaitu daging ayam potong (broiler). Selain dagingnya yang enak, harganya pun relatif murah dan mudah dijumpai. Terlepas dari itu, daging yang dikonsumsi akan menyisakan tulang yang nantinya menjadi limbah. Hal ini tentunya menimbulkan masalah lingkungan akibat sisa tulang yang tidak memiliki nilai ekonomi. Tulang juga sulit terurai sehingga hanya dapat mencemari lingkungan. Untuk itu diperlukan alternatif agar limbah tulang dapat bermanfaat dan memiliki nilai ekonomi.

Data dari Direktorat Jenderal Peternakan dan Kesehatan hewan, Kementrian Pertanian Republik Indonesia, menunjukkan perkiraan populasi ayam pedaging di Indonesia selama 5 tahun secara nasional berturut-turut 892 juta ekor (2007), 902 juta ekor (2008), 1 milyar ekor (2009), 987 juta ekor 
Sitti Musdalifah, Syamsidar Hs, Dan Suriani Dekolagenasi Limbah Tulang paha Ayam Broiler (Gallus domesticus) oleh $\mathcal{N a t r i u m ~ H i d r o k s i d a ~}$ ( $N a O H)$ untuk Penentuan Kadar Kalsium (Ca) Dan Fosfat $\left(\mathrm{PO}_{4}\right)$

(2010) dan 1 milyar ekor (2011). Meski demikian, jumlah tersebut masih belum bisa menutupi permintaan pasar daging asal unggas (Fadilah, 2013).

Limbah padat lebih dikenal sebagai sampah yang seringkali tidak dikehendaki kehadirannya karena tidak memiliki nilai ekonomis. Bila ditinjau secara kimiawi, limbah ini terdiri dari bahan kimia senyawa organik dan senyawa anorganik. Dengan konsentrasi dan kuantitas tertentu, kehadiran limbah dapat berdampak negatif terhadap lingkungan terutama bagi kesehatan manusia sehingga perlu dilakukan penanganan terhadap limbah (Astrina dkk, 2010).

Tabel 1. Komposisi Tulang Ayam Kerangka Binatang

\begin{tabular}{cc}
\hline Komponen & Kandungan $(\boldsymbol{\%})$ \\
\hline Air & $1,8-44,3$ \\
Lemak & $1,2-26,9$ \\
Kolagen & $15,8-32,8$ \\
Zat anorganik & $28,0-56,3$ \\
\hline \multicolumn{2}{c}{ (Sumber: Retno, 2012) }
\end{tabular}

(Sumber: Retno, 2012)

Tulang ayam adalah limbah padat yang dalam kehidupan sehari-hari dapat diasumsikan sebagai sampah atau sisa makanan yang sampai saat ini pemanfaatannya masih minim. Secara kimia komposisi utamanya adalah garam-garam terutama kalsium karbonat dan kalsium fosfat Serbuk tulang ayam memiliki potensi sebagai adsorben. Pemanfaatan ini memberikan dampak positif terhadap penanggulangannya sebagai sampah mengingat konsumsi daging ayam di restoran-restoran umum atau cepat saji serta dalam industri katering cukup besar (Darmayanto, 2009).

Limbah tulang ayam berpeluang untuk dimanfaatkan sebagai tepung tulang yang kaya akan kalsium dan fosfor karena dalam tulang ayam terdapat sekitar 28,0-56,3\% zat anorganik termasuk di dalamnya kalsium dan fosfor (Retno, 2012). Kalsium (Ca) merupakan elemen ke-5 terbanyak sekaligus kation terbanyak dalam tubuh manusia dan hewan (Hidayat, 2012). Kalsium dibutuhkan untuk proses pembentukan dan perawatan jaringan rangka tubuh serta beberapa kegiatan penting dalam tubuh seperti membantu dalam pengaturan transport ion-ion lainnya ke dalam maupun ke luar membran, berperan dalam penerimaan dan interpretasi pada impuls saraf, pembekuan darah dan pemompaan darah, kontraksi otot, menjaga keseimbangan hormon dan katalisator pada reaksi biologis (Trilaksani dkk, 2006). 
Sitti Musdalifah, Syamsidar Hs, Dan Suriani Dekolagenasi Limbah Tulang paha Ayam Broiler (Gallus domesticus) oleh Natrium Hidroksida

( $\mathcal{N a O H}$ ) untuk Penentuan Kadar Kalsium (Ca) Dan Fosfat (PO $\left.{ }_{4}\right)$

Fosfor merupakan mineral kedua terbanyak di dalam tubuh setelah kalsium, yaitu $1 \%$ dari berat badan. Kurang lebih $85 \%$ fosfor di dalam tubuh terdapat sebagai garam kalsium fosfat, yaitu bagian dari Kristal hidroksiapatit di dalam tulang dan gigi yang tidak dapat larut (Syarfaini, 2012). Fosfor yang terdapat bebas di alam, terutama di air, dominan berada di dalam bentuk senyawa $\mathrm{PO}_{4}{ }^{3-}$ (phosphate; fosfat). Karena itu penggunaan istilah 'fosfat' lebih umum digunakan (Dewi dan Masduqi, 2003).

Selain zat anorganik juga terdapat zat organik salah satunya yaitu kolagen. Kolagen merupakan protein fibriler/skleroprotein yang struktur molekulnya serabut (Winarno, 2002). Pemanasan serat kolagen dalam air sampai $60^{\circ}-70^{\circ} \mathrm{C}$ dapat memperpendek sampai $1 / 3-1 / 4$ dari panjang asalnya. Jika suhu dinaikkan sampai $80^{\circ} \mathrm{C}$, kolagen akan berubah menjadi gelatin (Deman, 1997).

Menurut Katili (2009), Sifat-sifat umum dan khusus kolagen adalah sebagai berikut:

1. Jika dididihkan di dalam air kolagen akan mengalami transformasi dari bentuk untaian tidak larut dan tidak tercerna menjadi gelatin, yaitu campuran polipeptida yang larut yang merupakan dasar pembentukan gelatin. Perubahan ini melibatkan hidrolisis beberapa ikatan kovalen pada kolagen, karena kolagen pada jaringan pengikat dan pembuluh yang menjadikan daging berbentuk liat.

2. Kolagen mengandung kira-kira $35 \%$ glisin dan kira-kira $11 \%$ alanin, persentase asam amino ini agak luar biasa tinggi. Yang lebih menonjol adalah kandungan prolin dan 4-hidroksiprolin yang tinggi, yaitu asam amino yang jarang ditemukan pada protein selain pada kolagen dan elastin. Bersama-sama prolin dan hidroksiprolin mencapai kira-kira $21 \%$ dari residu asam amino pada kolagen.

3. Komposisi asam amino kolagen tersebut mengandung empat jenis asam amino, tetapi rendah dalam hampir semua jenis asam amino lainnya yang merupakan dasar bagi kualitas gizi, gelatin relatif rendah sebagai sumber protein pangan. Protein pangan yang paling baik adalah mengandung 20 jenis asam amino, terutama golongan 10 yang disebut asam amino esensial.

Namun keberadaan kolagen kurang efektif dalam pembuatan tepung tulang sebab sulit dicerna oleh enzim yang terdapat dalam usus sehingga dibutuhkan suatu upaya untuk menghilangkan kolagen. Cara yang dapat ditempuh dalam penghilangan kolagen yaitu dengan proses deprotenasi atau dekolagenasi.

Dekolagenasi adalah proses pelepasan kolagen dari ikatannya. Kolagen yang terikat dapat didegradasi dengan perlakuan kimia yaitu pelarutan dalam 
Sitti Musdalifah, Syamsidar Hs, Dan Suriani Dekolagenasi Limbah Tulang paha Ayam Broiler (Gallus domesticus) oleh $\mathcal{N a t r i u m ~ H i d r o ß s i d a ~}$ $(\mathcal{N a O H})$ untuk Penentuan Kadar Kalsium (Ca) Dan Fosfat $\left(\mathrm{PO}_{4}\right)$

larutan basa kuat atau dengan perlakuan biologis. Dekolagenasi dilakukan dengan pemberian kondisi basa yang diikuti pemanasan selama rentang waktu tertentu. Sebagai basa, banyak dipilih $\mathrm{NaOH}$ sebab selain lebih efektif bahan ini juga relatif murah dan mudah didapatkan. Pemberian basa dimaksudkan untuk mendenaturasi protein menjadi bentuk primernya yang akan mengendap (Ermawati dkk, 2009).

Prinsip penghilangan protein dari suatu bahan dapat dilakukan dengan cara hidrolisis menggunakan pelarut tertentu. Protein akan terhidrolisis apabila dicampur dengan asam atau alkali kuat atau enzim proteolitik melalui proses pemecahan protein secara bertahap menjadi molekul-molekul peptida dan asam-asam amino (Fessenden dan Fessenden, 1986). Hidrolisa kolagen menjadi gelatin dilakukan dalam kisaran suhu antara $60-90^{\circ} \mathrm{C}$. Semakin tinggi suhu pada proses hidrolisa, maka reaksi akan semakin cepat, tetapi warna gelatin yang dihasilkan akan semakin gelap karena protein dalam kolagen rusak (Retno, 2012).

\title{
2. METODE PENELITIAN
}

\section{Waktu dan Tempat Penelitian}

Penelitian ini dilakukan pada tanggal 07 September - 18 Desember 2015 di Laboratorium Anorganik, Analitik dan Riset Fakultas Sains dan Teknologi UIN Alauddin Makassar.

\begin{abstract}
Alat
Adapun alat-alat yang digunakan yaitu Spektrofotometer Serapan Atom (SSA) Varian AA240ES, Spektrofotometer UV-Vis Varian Cary 50 Conc, ayakan 100 mesh, autoklaf, oven, neraca analitik, $\mathrm{pH}$ meter, hot plate, blender, alat-alat gelas, termometer $100^{\circ} \mathrm{C}$, toples kaca, statif dan klem, corong, botol pereksi, rak tabung, kasa, kain blacu, spatula, batang pengaduk dan saringan.
\end{abstract}

\section{Bahan}

Adapun bahan-bahan yang digunakan yaitu aluminium foil, ammonium molibdat $\left(\left(\mathrm{NH}_{4}\right)_{6} \mathrm{MoO}_{24} .4 \mathrm{H}_{2} \mathrm{O}\right)$, asam nitrat $\left(\mathrm{HNO}_{3}\right)$ p.a., asam perklorat $\left(\mathrm{HClO}_{4}\right)$ p.a, asam sulfat $\left(\mathrm{H}_{2} \mathrm{SO}_{4}\right)$ p.a, aquabides $\left(\mathrm{H}_{2} \mathrm{O}\right)$, aquades $\left(\mathrm{H}_{2} \mathrm{O}\right)$, besi sulfat hidrat $\left(\mathrm{FeSO}_{4} \cdot 7 \mathrm{H}_{2} \mathrm{O}\right)$, kalium dihidrogen fosfat $\left(\mathrm{KH}_{2} \mathrm{PO}_{4}\right)$, kertas whatman no. 42, larutan induk kalsium (Ca) $1000 \mathrm{mg} / \mathrm{L}$, natrium hidroksida $(\mathrm{NaOH}) 4 \%$ dan tulang paha ayam broiler. 


\section{Prosedur Kerja}

\section{Proses Dekolagenasi dan Pembuatan Tepung Tulang}

Tulang paha ayam broiler direbus dan dibersihkan. Setelah dibersihkan, dilakukan proses penghilangan lemak (degreasing) dengan cara dimasak selama 30 menit pada suhu $80^{\circ} \mathrm{C}$ kemudian tulang ditiriskan dan dijemur di bawah sinar matahari selama 1 jam. Tulang dipotong dengan ukuran $\pm 2 \mathrm{~cm}$. Tulang ditimbang sebanyak $100 \mathrm{~g}$ dan direndam dengan larutan natrium hidroksida $(\mathrm{NaOH}) 4 \%$ dengan perbandingan berat terhadap volume basa (1:4) selama 48 jam kemudian disaring. Tulang kemudian dicuci dengan menggunakan aquabides sampai pH-nya netral. Proses selanjutnya tulang dimasukkan ke dalam autoklaf $\left(121^{\circ} \mathrm{C}, 1 \mathrm{~atm}\right)$ selama $3 \mathrm{jam}$. Tulang dikeringkan dalam oven dengan suhu $80^{\circ} \mathrm{C}$ selama 24 jam. Tahap akhir proses pembuatan tepung tulang adalah pengayakan. Tulang ditepungkan menggunakan blender. Tepung yang dihasilkan diayak menggunakan ayakan dengan ukuran 100 mesh agar diperoleh tepung tulang yang halus. Mengulangi perlakuan yang sama dengan variasi waktu perendaman 72 jam dan 96 jam (Thalib, 2009).

\section{Destruksi Basah dan Pembuatan Larutan Sampel}

Timbang 1 gram tepung tulang ayam kemudian tambahkan $2 \mathrm{~mL}$ aquabides dan $5 \mathrm{~mL}$ asam nitrat $\left(\mathrm{HNO}_{3}\right)$ p.a, tambahkan aquabides hingga volumenya $50 \mathrm{~mL}$. Sampel dipanaskan di atas hotplate sampai volumenya 40 $\mathrm{mL}$. Setelah volumenya mencapai $40 \mathrm{~mL}$ dan timbul asap berwarna putih, tambahkan asam perklorat $\left(\mathrm{HClO}_{4}\right)$ p.a. sebanyak $1 \mathrm{~mL}$ hingga larutan berwarna kuning jernih. Panaskan kembali hingga volumenya $20 \mathrm{~mL}$. Saring larutan sampel ke dalam labu takar $100 \mathrm{~mL}$ dengan kertas whatman no. 42 kemudian volumenya ditepatkan sampai tanda batas dengan aquabides dan homogenkan. Simpan dalam botol gelap. Melakukan secara duplo. Mengulangi perlakuan yang sama pada tepung tulang ayam broiler hasil perendaman dengan variasi waktu 72 dan 96 jam.

\section{Penentuan Kadar Kalsium (Ca)}

Pembuatan larutan induk kalsium (Ca) $1000 \mathrm{mg} / \mathrm{L}$

Menimbang kalsium karbonat $\left(\mathrm{CaCO}_{3}\right)$ sebanyak 0,25 g kemudian dimasukkan dalam labu takar $100 \mathrm{~mL}$ lalu diencerkan dengan aquabides sampai tanda batas dan dihomogenkan. 
Sitti Musdalifah, Syamsidar Hs, Dan Suriani Dekolagenasi Limbah Tulang paha Ayam Broiler (Gallus domesticus) oleh Natrium Hidroßsida (NaOH) untuk Penentuan Kadar Kalsium (Ca) Dan Fosfat (PO $\left.{ }_{4}\right)$

Pembuatan Larutan Deret Standar Kalsium (Ca) 0,0; 10; 20; 40; 80 dan 160 $m g / L$

Sebanyak 0,$0 ; 0,5 ; 1,0 ; 2,0 ; 4,0$ dan $8,0 \mathrm{~mL}$ larutan induk kalsium $(\mathrm{Ca})$ $1000 \mathrm{mg} / \mathrm{L}$ dimasukkan dalam labu takar $50 \mathrm{~mL}$ lalu diencerkan dengan aquabides sampai tanda batas dan dihomogenkan. Kemudian diukur absorbansinya dengan menggunakan Spektrofotometer Serapan Atom pada panjang gelombang $239,9 \mathrm{~nm}$.

\section{Penetapan kadar kalsium (Ca) dalam sampel}

Larutan sampel hasil dekstruksi sebanyak $10 \mathrm{ml}$ dimasukkan ke dalam labu takar $100 \mathrm{ml}$ dan diencerkan dengan aquabides hingga tanda batas (Faktor Pengenceran $=100 \mathrm{~mL} / 10 \mathrm{~mL}=10$ kali untuk kalsium). Larutan diukur absorbansinya dengan spektrofotometer serapan atom pada panjang gelombang $239,9 \mathrm{~nm}$.

\section{Penentuan Kadar Fosfat $\left(\mathrm{PO}_{4}\right)$}

Pembuatan larutan induk fosfat $1000 \mathrm{mg} / \mathrm{L}$

Menimbang 0,1463 g kalium dihidrogen fosfat $\left(\mathrm{KH}_{2} \mathrm{PO}_{4}\right)$ dan dilarutkan dalam $100 \mathrm{~mL}$ aquabides. Simpan dalam botol gelap.

\section{Pembuatan larutan baku fosfat $100 \mathrm{mg} / \mathrm{L}$}

Memipet $5 \mathrm{~mL}$ larutan induk fosfat $\left(\mathrm{PO}_{4}\right) 1000 \mathrm{mg} / \mathrm{L}$ ke dalam labu takar $50 \mathrm{~mL}$ lalu diencerkan dengan aquabides sampai tanda batas dan dihomogenkan.

\section{Pembuatan larutan baku fosfat $10 \mathrm{mg} / \mathrm{L}$}

Memipet $5 \mathrm{~mL}$ larutan baku fosfat $\left(\mathrm{PO}_{4}\right) 100 \mathrm{mg} / \mathrm{L}$ ke dalam labu takar $50 \mathrm{~mL}$ lalu diencerkan dengan aquabides sampai tanda batas dan dihomogenkan.

\section{Pembuatan larutan A}

Menimbang ammonium molibdat $\left\{\left(\mathrm{NH}_{4}\right)_{6} \mathrm{MoO}_{24} .4 \mathrm{H}_{2} \mathrm{O}\right\}$ sebanyak $10 \mathrm{~g}$ ditambah $60 \mathrm{~mL}$ aquabides kemudian ditambahkan $28 \mathrm{~mL}$ asam sulfat $\left(\mathrm{H}_{2} \mathrm{SO}_{4}\right)$ p.a dan 5,0001 g besi sulfat hidrat $\left(\mathrm{FeSO}_{4} .7 \mathrm{H}_{2} \mathrm{O}\right)$ lalu dijadikan $100 \mathrm{~mL}$ dengan aquabides.

Pembuatan larutan deret standar fosfat 0,0;0,2;0,4;0,6;0,8 dan 1,0 mg/L

Sebanyak 0,0; 1,0;2,0; 3,0; 4,0 dan 5,0 mL larutan baku fosfat $10 \mathrm{mg} / \mathrm{L}$ dipipet dan masing-masing volume tersebut ditambahkan $2 \mathrm{~mL}$ larutan A serta 
Sitti Musdalifah, Syamsidar Hs, Dan Suriani Dekolagenasi Limbah Tulang paha Ayam Broiler (Gallus domesticus) oleh Natrium Hidroksida ( $\mathcal{N a O H}$ ) untuk Penentuan Kadar Kalsium (Ca) Dan Fosfat ( $\left(\mathrm{OO}_{4}\right)$

aquabides hingga $50 \mathrm{~mL}$. Kemudian diukur absorbansinya dengan menggunakan Spektrofotometer UV-Vis pada panjang gelombang $660 \mathrm{~nm}$.

\section{Penetapan kadar fosfat $\left(\mathrm{PO}_{4}\right)$ dalam sampel}

Sebanyak 0,3 $\mathrm{mL}$ sampel hasil destruksi dipipet ke dalam tabung reaksi lalu ditambahkan 2,7 mL aquabides dan $2 \mathrm{~mL}$ larutan A kemudian dihomogenkan (Faktor Pengenceran $100 \mathrm{~mL} / 2,5 \mathrm{~mL}=40$ kali untuk fosfat). Larutan dipipet sebanyak $3 \mathrm{~mL}$ ke dalam kuvet dan dibaca pada spektrofotometer UV-Vis dengan panjang gelombang $660 \mathrm{~nm}$ (Tangalayuk dkk, 2015).

\section{HASIL DAN PEMBAHASAN}

Tulang ayam merupakan salah satu limbah padat yang dapat dimanfaatkan sebagai tepung tulang yang kaya akan kalsium (Ca) dan fosfat $\left(\mathrm{PO}_{4}\right)$. Tulang ayam terdiri dari senyawa organik maupun senyawa anorganik yang memiliki banyak manfaat. Komponen organik yang utama yaitu protein sedangkan komponen anorganik yaitu kalsium, karbonat, potassium, sodium, magnesium, fosfor dan lain-lain. Tulang ayam yang digunakan pada penelitian ini yaitu tulang ayam broiler (Gallus domesticus) bagian paha yang diperoleh dari limbah domestik.

Penelitian ini diawali dengan pengumpulan tulang paha ayam broiler (Gallus domesticus) sebanyak 300 gram. Tulang tersebut direbus dan dibersihkan untuk menghilangkan sisa daging yang masih menempel pada tulang dan untuk menghilangkan lemak yang terdapat pada tulang. Selanjutnya dipotong dengan ukuran kecil untuk memperluas permukaan tulang agar saat proses dekolagenasi, protein yang terdapat dalam tulang mudah keluar. Proses dekolagenasi ini menggunakan larutan natrium hidroksida $(\mathrm{NaOH})$ dengan perbandingan (1:4) dengan variasi waktu perendaman yaitu 48, 72 dan 96 jam. Saat perendaman tulang akan terjadi proses hidrolisis dimana larutan natrium hidroksida $(\mathrm{NaOH})$ akan menghidrolisis protein dan komponen kolagen yang terdapat dalam tulang.

Penggunaan basa kuat yaitu natrium hidroksida $(\mathrm{NaOH})$ dalam proses dekolagenasi dimaksudkan untuk melarutkan protein dalam tulang karena pada suasana basa, kalsium dalam tulang bersama dengan fosfor membentuk kalsium fosfat. Kalsium fosfat adalah kristal mineral yang memiliki sifat tidak larut pada $\mathrm{pH}$ alkali (Almatsier, 2004). Kalsium yang tidak larut selama perendaman akan tertinggal dan mengendap dalam matriks-matriks tulang sehingga mampu 
Sitti Musdalifah, Syamsidar Hs, Dan Suriani Dekolagenasi Limbah Tulang paha Ayam Broiler (Gallus domesticus) oleh Natrium Hidroksida $(\mathcal{N a O H})$ untuk Penentuan Kadar Kalsium (Ca) Dan Fosfat $\left(\mathrm{PO}_{4}\right)$

meningkatkan proporsi kalsium dalam tepung tulang. Berikut reaksi hidrolisis untuk kalsium fosfat:

$$
3 \mathrm{Ca}^{2+}{ }_{(\mathrm{aq})}+2 \mathrm{PO}_{4}{ }^{3-}{ }_{(\mathrm{aq})} \longrightarrow \mathrm{Ca}_{3}\left(\mathrm{PO}_{4}\right)_{2(\mathrm{aq})}
$$

Gambar 1. Reaksi Pembentukan Kalsium Fosfat(Sumber: Darmayanto, 2009)

Selanjutnya tulang dicuci dengan menggunakan air suling. Pencucian ini bertujuan untuk menetralkan tulang agar saat pembacaan pada alat instrumen tidak merusak alat. Proses penetralan ini berlangsung selama \pm 1 bulan. Lamanya penetralan ini dipengaruhi oleh larutan $\mathrm{NaOH}$ yang digunakan merupakan basa kuat sehingga untuk mencapai $\mathrm{pH}$ netral $(6,5-7,5)$ dibutuhkan waktu yang cukup lama. Tahap selanjutnya yaitu autoklaf selama 3 jam ( $\mathrm{T}=$ $\left.121^{\circ} \mathrm{C}, \mathrm{P}=1 \mathrm{~atm}\right)$ untuk mensterilkan tulang dari mikroba dan melunakkan tulang. Pengeringan tulang dalam oven selama 24 jam pada suhu $80^{\circ} \mathrm{C}$ berfungsi untuk menghilangkan kadar air yang terdapat dalam tulang. Tahap akhir yaitu pembuatan tepung tulang dimana tulang diblender untuk memudahkan saat proses pengayakan dan diayak dengan ayakan ukuran 100 mesh agar tepung tulang yang dihasilkan halus.

Destruksi merupakan suatu perlakuan pemecahan senyawa menjadi unsur-unsurnya sehingga dapat dianalisis. Istilah destruksi ini disebut juga perombakan, yaitu dari bentuk organik logam menjadi bentuk logam-logam anorganik. Pada penelitian ini, asam-asam pengoksidasi yang digunakan untuk mendestruksi tepung tulang yaitu asam nitrat $\left(\mathrm{HNO}_{3}\right)$ dan asam perklorat $\left(\mathrm{HClO}_{4}\right)$. Tujuan dari proses destruksi ini yaitu untuk memutuskan ikatan unsur logam dengan komponen lain dalam matriks sehingga unsur tersebut berada dalam keadaan bebas sebab kandungan matriks atau ion-ion lain dapat mengganggu proses analisis logam dengan spektroskopi serapan atom. Hal ini mengakibatkan akurasi hasil analisis menjadi rendah. Oleh karena itu, sebelum analisis dilakukan destruksi untuk menghilangkan/memisahkan kandungan ion lain dengan perlakuan awal diharapkan kesalahan pada saat analisis dapat dikecilkan seminimal mungkin (Kristianingrum, 2012). Penambahan asam nitrat $\left(\mathrm{HNO}_{3}\right)$ berfungsi sebagai pengoksidasi logam yang terdapat dalam sampel tepung tulang. Selain asam nitrat $\left(\mathrm{HNO}_{3}\right)$ juga digunakan asam lain yaitu asam perklorat $\left(\mathrm{HClO}_{4}\right)$ yang merupakan oksidator yang sangat kuat. Fungsi dari asam ini yaitu untuk menyempurnakan penguraian dan menghilangkan zat-zat pengotor pada ion logam yang terdapat dalam sampel sehingga tidak ada lagi zat-zat pengotor yang mengganggu saat proses analisis. 
Sitti Musdalifah, Syamsidar Hs, Dan Suriani Dekolagenasi Limbah Tulang paha Ayam Broiler (Gallus domesticus) oleh Natrium Hidroksida ( $N a O H)$ untuk Penentuan Kadar Kalsium (Ca) Dan Fosfat $\left(\mathrm{PO}_{4}\right)$

Absorbansi deret standar kalsium (Ca) diukur dengan menggunakan Spektrofotometer Serapan Atom (SSA) dengan panjang gelombang 239,9 nm. Berikut disajikan tabel di bawah ini:

Tabel 1.Absorbansi Larutan Standar Kalsium (Ca)

\begin{tabular}{ccc}
\hline No. & Konsentrasi (ppm) & Absorbansi \\
\hline 1 & 0 & 0 \\
2 & 10 & 0,0078 \\
3 & 20 & 0,0156 \\
4 & 40 & 0,0280 \\
5 & 80 & 0,0561 \\
6 & 160 & 0,1376 \\
\hline
\end{tabular}

Berdasarkan tabel pengukuran absorbansi larutan standar kalsium (Ca) di atas, maka diperoleh grafik sebagai berikut:

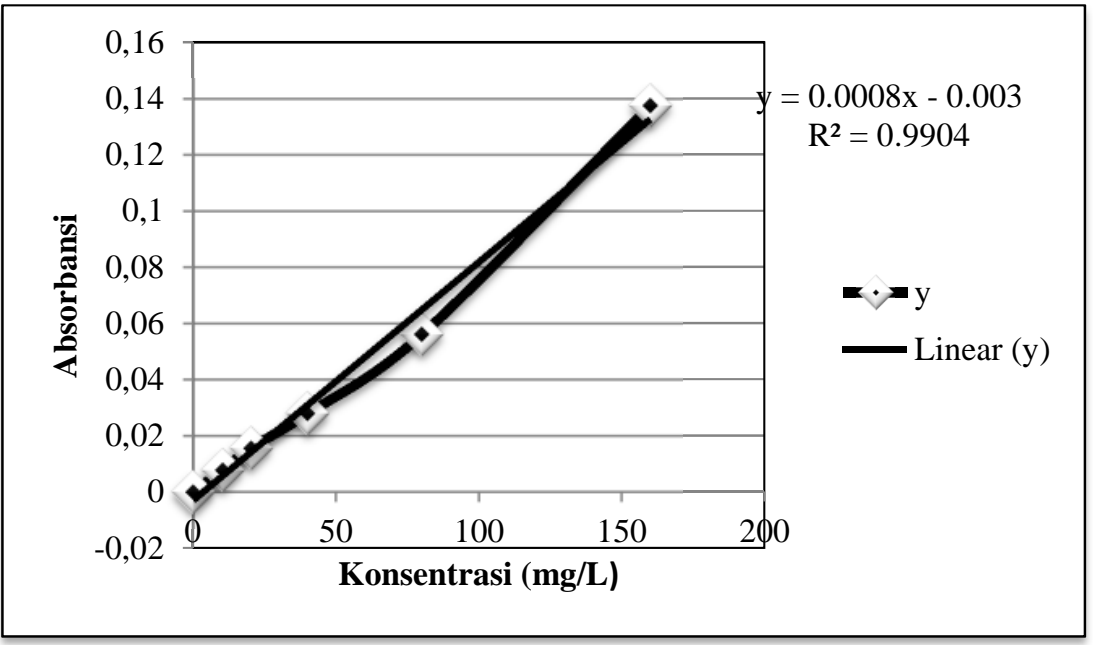

Gambar 2. Grafik Absorbansi Larutan Standar Kalsium (Ca)

Analisis kadar kalsium ( $\mathrm{Ca}$ ) pada larutan sampel terhadap tulang paha ayam broiler (Gallus domesticus) dilakukan secara duplo. Berikut disajikan tabel di bawah ini: 
Sitti Musdalifah, Syamsidar Hs, Dan Suriani Dekolagenasi Limbah Tulang paha Ayam Broiler (Gallus domesticus) oleh Natrium Hidroksida ( $N a O H)$ untuk Penentuan Kadar Kalsium (Ca) Dan Fosfat $\left(\mathrm{PO}_{4}\right)$

Tabel 2.Kadar Kalsium (Ca) pada Tulang Paha Ayam Broiler

\begin{tabular}{|c|c|c|c|c|c|c|}
\hline No & $\begin{array}{c}\text { Waktu } \\
\text { Perendaman } \\
\text { (Jam) }\end{array}$ & Absorbansi & $\begin{array}{l}\text { Absorbansi } \\
\text { Rata-rata }\end{array}$ & $\begin{array}{c}\text { Kadar } \\
\text { Kalsium } \\
(\mathrm{mg} / \mathrm{L})\end{array}$ & $\begin{array}{c}\text { Kadar } \\
\text { Kalsium(mg/kg) }\end{array}$ & $\begin{array}{l}\text { \% Kadar } \\
\text { Kalsium }\end{array}$ \\
\hline 1 & $48 \mathrm{AB}_{1}$ & 0,1303 & \multirow{2}{*}{0,1316} & \multirow{2}{*}{168,25} & \multirow{2}{*}{168165,92} & \multirow{2}{*}{16,8166} \\
\hline 2 & $48 \mathrm{AB}_{2}$ & 0,1329 & & & & \\
\hline 3 & $72 \mathrm{AB}_{1}$ & 0,1323 & \multirow{2}{*}{0,1333} & \multirow{2}{*}{170,375} & \multirow{2}{*}{170323,90} & \multirow{2}{*}{17,0324} \\
\hline 4 & $72 \mathrm{AB}_{2}$ & 0,1343 & & & & \\
\hline 5 & $96 \mathrm{AB}_{1}$ & 0,1352 & \multirow{2}{*}{0,1348} & \multirow{2}{*}{172,25} & \multirow{2}{*}{172215,56} & \multirow{2}{*}{17,2216} \\
\hline 6 & $96 \mathrm{AB}_{2}$ & 0,1343 & & & & \\
\hline
\end{tabular}

Berdasarkan tabel 2 diperoleh kadar kalsium $(\mathrm{Ca})$ tepung tulang paha ayam mengalami peningkatan seiring lamanya waktu perendaman oleh larutan $\mathrm{NaOH}$. Peningkatan ini disebabkan karena semakin lama waktu perendaman dalam larutan $\mathrm{NaOH}$ memungkinkan banyaknya kalsium yang mengendap dalam matriks-matriks tulang sehingga semakin tinggi pula kalsium $(\mathrm{Ca})$ yang dihasilkan. Pada penelitian ini, waktu maksimal untuk memperoleh kadar kalsium (Ca) tertinggi yaitu dengan perendaman tulang ayam selama 96 jam.

Absorbansi deret standar fosfat $\left(\mathrm{PO}_{4}\right)$ diukur dengan menggunakan Spektrofotometer UV-Vis pada panjang gelombang $660 \mathrm{~nm}$. Berikut disajikan tabel di bawah ini:

Tabel 3.Absorbansi Larutan Standar Fosfat $\left(\mathrm{PO}_{4}\right)$

\begin{tabular}{ccc}
\hline No. & Konsentrasi (ppm) & Absorbansi \\
\hline 1 & 0 & 0 \\
2 & 0,2 & 0,024 \\
3 & 0,4 & 0,0423 \\
4 & 0,6 & 0,0602 \\
5 & 0,8 & 0,0753 \\
6 & 1,0 & 0,0967 \\
\hline
\end{tabular}

Berdasarkan tabel pengukuran absorbansi larutan standar fosfat $\left(\mathrm{PO}_{4}\right) \mathrm{di}$ atas, maka diperoleh grafik sebagai berikut: 
Sitti Musdalifah, Syamsidar Hs, Dan Suriani Dekolagenasi Limbah Tulang paha Ayam Broiler (Gallus domesticus) oleh Natrium Hidroksida

( $N a O H)$ untuk Penentuan Kadar Kalsium (Ca) Dan Fosfat $\left(\mathrm{PO}_{4}\right)$

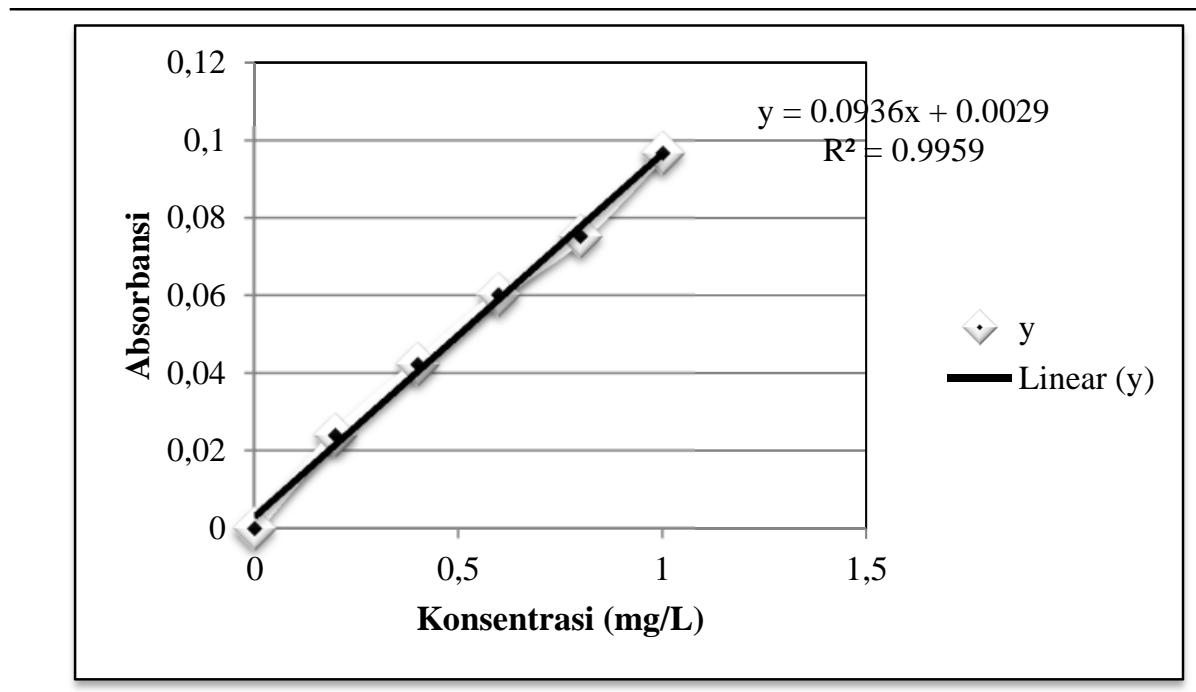

Gambar 3. Grafik Absorbansi Larutan Standar Fosfat $\left(\mathrm{PO}_{4}\right)$

Analisis kadar fosfat $\left(\mathrm{PO}_{4}\right)$ pada larutan sampel terhadap tulang paha ayam broiler (Gallus domesticus) dilakukan secara duplo. Berikut disajikan tabel di bawah ini:

Tabel 4. Kadar Fosfat $\left(\mathrm{PO}_{4}\right)$ pada Tulang Paha Ayam Broiler

\begin{tabular}{ccccccc}
\hline No & $\begin{array}{c}\text { Waktu } \\
\text { Perendaman } \\
(\text { Jam) }\end{array}$ & Absorbansi & $\begin{array}{c}\text { Absorbansi } \\
\text { Rata-rata }\end{array}$ & $\begin{array}{c}\text { Kadar } \\
\text { Fosfat } \\
(\mathbf{m g} / \mathbf{L})\end{array}$ & $\begin{array}{c}\text { Kadar } \\
\text { Fosfat } \\
(\mathbf{m g} / \mathbf{k g})\end{array}$ & $\begin{array}{c}\text { \% Kadar } \\
\text { Fosfat }\end{array}$ \\
\hline 1 & $48 \mathrm{AB}_{1}$ & 0,0332 & 0,0335 & 0,3269 & 1306,95 & 0,1307 \\
2 & $48 \mathrm{AB}_{2}$ & 0,0338 & & & & \\
\hline 3 & $72 \mathrm{AB}_{1}$ & 0,0326 & 0,0343 & 0,3355 & 1341,60 & 0,1342 \\
4 & $72 \mathrm{AB}_{2}$ & 0,0360 & & & & \\
\hline 5 & $96 \mathrm{AB}_{1}$ & 0,0380 & 0,0370 & 0,3643 & 1456,91 & 0,1457 \\
6 & $96 \mathrm{AB}_{2}$ & 0.0360 & & & & \\
\hline
\end{tabular}

Hasil penelitian pada tabel 4 menunjukkan bahwa lama perendaman tulang paha ayam mempengaruhi peningkatan kadar fosfat $\left(\mathrm{PO}_{4}\right)$. Pada tabel 4 . jelas bahwa pengaruh waktu perendaman dengan lama waktu perendaman 48 , 72 dan 96 jam menghasilkan kadar fosfat $\left(\mathrm{PO}_{4}\right)$ yang berbeda dimana semakin lama perendaman maka kadar fosfat $\left(\mathrm{PO}_{4}\right)$ semakin meningkat. Hal ini membuktikan bahwa lama perendaman 96 jam merupakan waktu yang maksimal untuk menghasilkan kadar fosfat $\left(\mathrm{PO}_{4}\right)$ yang dihasilkan melalui dekolagenasi tulang ayam dengan menggunakan larutan $\mathrm{NaOH}$. 


\section{PENUTUP}

\section{Kesimpulan}

Kesimpulan yang dapat ditarik pada penelitian ini yaitu sebagai berikut:

1. Kadar kalsium $(\mathrm{Ca})$ yang terdapat dalam limbah tulang paha ayam broiler (Gallus domesticus) dengan menggunakan metode Spektrofotometer Serapan Atom (SSA) yaitu pada perendaman 48 jam menghasilkan kadar kalsium $(\mathrm{Ca})$ sebesar 168165,92 mg/kg, pada perendaman 72 jam sebesar $170323,90 \mathrm{mg} / \mathrm{kg}$ dan pada perendaman 96 jam sebesar 172215,56 $\mathrm{mg} / \mathrm{kg}$.

2. Kadar fosfat $\left(\mathrm{PO}_{4}\right)$ yang terdapat dalam limbah tulang paha ayam broiler (Gallus domesticus) dengan menggunakan metode Spektrofotometer UVVis yaitu pada perendaman 48 jam menghasilkan kadar fosfat $\left(\mathrm{PO}_{4}\right)$ sebesar 1306,95 mg/kg, pada perendaman 72 jam sebesar 1341,60 mg/kg dan pada perendaman 96 jam sebesar $1456,91 \mathrm{mg} / \mathrm{kg}$.

3. Waktu perendaman tulang paha ayam broiler (Gallus domesticus) oleh natrium hidroksida $(\mathrm{NaOH})$ berpengaruh terhadap kadar kalsium $(\mathrm{Ca})$ dan fosfat $\left(\mathrm{PO}_{4}\right)$ karena semakin lama tulang ayam broiler (Gallus domesticus) direndam semakin tinggi pula kadar kalsium $(\mathrm{Ca})$ dan fosfat $\left(\mathrm{PO}_{4}\right)$ yang diperoleh.

\section{Saran}

Saran yang dapat disampaikan oleh peneliti yaitu:

1. Untuk peneliti selanjutnya sebaiknya meningkatkan variasi waktu perendaman lebih dari 96 jam untuk mendapatkan waktu perendaman yang optimal.

2. Diharapkan untuk peneliti selanjutnya menganalisis kadar kalsium karbonat $\left(\mathrm{CaCO}_{3}\right)$ dalam limbah tulang ayam broiler (Gallus domesticus).

\section{DAFTAR PUSTAKA}

Almatsier, Sunita, 2004, Prinsip Dasar Ilmu Gizi,Jakarta: Gramedia Pustaka Utama.

Astrina, Aninda Rahma,et. al.,Pemanfaatan Limbah Tulang Ikan Bandeng (Chanos chanos) sebagai Bakso Berkalsium Tinggi, Karya Tulis Ilmiah, Malang: Universitas Negeri Malang.

Darmayanto,2009, Penggunaan Serbuk Tulang Ayam Sebagai Penurun Intensitas Warna Air Gambut,Tesis, Medan: Universitas Sumatera Utara. 
Sitti Musdalifah, Syamsidar Hs, Dan Suriani Dekolagenasi Limbah Tulang paha Ayam Broiler (Gallus domesticus) oleh Natrium Hidroßsida (NaOH) untuk Penentuan Kadar Kalsium (Ca) Dan Fosfat (PO $\left.{ }_{4}\right)$

Deman, John, M., 1997, Kimia Makanan. Terj. Kokasih Padmawinata, Bandung: Penerbit ITB.

Dewi, Devina, Fitrika, dan Ali Masduqi, 2003,Penyisihan Fosfat dengan Proses Kristalisasi dalam Reaktor Terfluidisasi Menggunakan Media Pasir Silika,Jurnal Purifikasi,4(4): 151-156.

Ermawati, Yunita, et. al., 2009,Pemanfaatan Kitosan dari Limbah Rajungan (Portunus pelagicus) sebagai Antimikroba pada Obat Kumur, Karya Ilmiah, Yogyakarta: Fakultas Farmasi UGM.

Fadilah, Roni, 2013, Beternak Ayam Broiler, Jakarta: PT AgroMedia Pustaka. Fessenden, Ralp, J., Joan, S., 1986, Kimia Organik Jilid 2,Jakarta: Erlangga.

Hidayat, Muhammad Nur, 2012, Ilmu Dasar Nutrisi Ternak, Makassar: Alauddin University Press.

Katili, Abubakar Sidik, 2009, Struktur dan Fungsi Protein Kolagen,Jurnal Pelangi Ilmu, 2(5): 19-29.

Kristianingrum, Susila, 2012,Kajian Berbagai Proses Destruksi Sampel dan Efeknya,Prosiding Seminar Nasional Penelitian,Pendidikan dan Penerapan MIPA, Fakultas MIPA, Universitas Negeri Yogyakarta

Retno, Dyah Tri, 2012,Pembuatan Gelatin dari Tulang Ayam dengan Proses hidrolisa,Prosiding Seminar Nasional Aplikasi Sains dan Teknologi (SNAST) Periode III, Yogyakarta: Universitas Pembangunan Nasional.

Syarfaini, 2012, Dasar-Dasar Ilmu Gizi, Makassar: Alauddin University Press.

Tangalayuk, Reggy Raisa,et. al., 2015,Kadar Kalsium dan Fosfor pada Tulang Tikus Betina yang diberi Tepung Tempe Rendah Lemak,Buletin Veteriner Udayana,7(1):59-65.

Thalib, A., 2009,Pemanfaatan Tepung Tulang Ikan Madidihang (Thunnus albacares) sebagai Sumber Kalsium dan Fosfor untuk Meningkatkan Nilai Gizi Makron Kenari,Tesis,Bogor: Sekolah Pascasarjana IPB,

Trilaksani, Wini,et. al., 2006,Pemanfaatan Limbah Tulang Ikan Tuna (Thunnus sp.) sebagai Sumber Kalsium dengan Metode Hidrolisis Protein,Buletin Teknologi Hasil Perikanan, 9(2): 34-43.

Winarno, F.G., 2002,Kimia Pangan dan Gizi, Jakarta: PT Gramedia Pustaka Utama. 